\title{
STUDI HUBUNGAN SUBSTRAT DASAR DAN KANDUNGAN BAHAN ORGANIK DALAM SEDIMEN DENGAN KELIMPAHAN HEWAN MAKROBENTHOS DI MUARA SUNGAI SAYUNG KABUPATEN DEMAK
}

\author{
Rella Nur Taqwa, Max Rudolf Muskananfola ${ }^{l}$, Ruswahyuni
}

Program Studi Manajemen Sumberdaya Perairan, Jurusan Perikanan

Fakultas Perikanan dan Ilmu Kelautan, Universitas Diponegoro

\begin{abstract}
ABSTRAK
Muara sungai Sayung merupakan daerah yang telah mengalami perubahan kondisi ekologi perairan yang disebabkan karena pengaruh pasang tertinggi (rob). Daerah tersebut telah berubah menjadi daerah tergenang dan banyak didominasi oleh substrat berlumpur. Substrat lumpur kaya akan bahan organik dan akan menjadi cadangan makanan bagi hewan makrobenthos yang hidup di muara sungai. Tujuan dari penelitian ini adalah untuk mengetahui hubungan substrat dasar dan kandungan bahan organik dalam sedimen dengan kelimpahan hewan makrobenthos, dan untuk mengetahui kondisi lingkungan Muara Sungai Sayung berdasarkan nilai keanekaragaman dan keseragaman hewan makrobenthos. Penelitian ini berdasarkan studi kasus dan menggunakan metode purposive sampling untuk pengambilan sampel. Hasil penelitian dari ketiga stasiun di Muara Sungai Sayung didapatkan kelimpahan hewan makrobenthos berkisar antara 363 $4829 \mathrm{ind} / \mathrm{m}^{3}$. Hewan makrobenthos yang didapatkan selama penelitian terdiri dari 3 kelas yaitu Polychaeta, Gastropoda, dan Bivalvia. Hasil penelitian pada stasiun I nilai indeks keanekaragaman sebesar 0,63, indeks keseragaman sebesar 0,57, Stasiun II nilai indeks keanekaragaman sebesar 0,13, indeks keseragaman sebesar 0,19, dan Stasiun III diperoleh nilai indeks keanekaragaman sebesar 1,79 dan indeks keseragaman sebesar 0,78 . Nilai keanekaragaman tergolong dalam kategori rendah sampai sedang yang menunjukkan bahwa kondisi lingkungan sudah tidak layak untuk kehidupan hewan makrobenthos di dalamnya dan nilai keseragaman termasuk dalam kategori kecil sampai tinggi yang menunjukkan bahwa komposisi jenis hewan makrobenthos tidak sama dan kondisi ekosistemnya tidak stabil sehingga rawan akan terjadinya penurunan pada fungsi ekosistemnya. Berdasarkan nilai uji regresi sederhana dan uji regresi berganda dimana nilai koefisien korelasi berkisar $0,9<\mathrm{r} \leq 1,0$ menunjukkan bahwa kelimpahan hewan makrobenthos memiliki hubungan yang sangat kuat dan memiliki korelasi yang sangat nyata dengan jenis substrat dasar dan kandungan bahan organik dalam sedimen.
\end{abstract}

Kata Kunci : Substrat Dasar, Bahan Organik, Makrobenthos, Muara Sungai Sayung

\begin{abstract}
Sayung estuary is an area that has change in ecological water condition which caused by high tide (rob). This area has become flooded area and dominated mostly by silt substrate. Silt substrate that rich organic matter and will become food reserves for macrobenthos in estuary. The purpose of this research are to know the relations of bottom substrate and organic matter in sediment with macrobenthos abundance, and to know waters condition of Sayung estuary be based on diversity index and uniformity index macrobenthos. This research based on case study and using the purposive sampling menthod for taking samples. The result of research from third station at Sayung estuary obtained macrobenthos abundance range between $363-4829$ ind $/ \mathrm{m}^{3}$. Macrobenthos were obtained during the research consist of 3 classes that is Polychaeta, Gastropod, and Bivalves. The result of this research on the station I obtained diversity index was 0,63 , and uniformity index is 0,57 . Station II obtained diversity index was 0,13 , and uniformity index is 0,19 , and Station III obtained diversity index was 1,79 and uniformity index is 0,78 . Diversity index included in a category low to mid that showed environment condition has not worthy to macrobenthos life inside and uniformity index included in a category low to high that showed composition kinds of macrobenthos not the same and the condition of their ecosystems unstable so prone will decline in ecosystem function. Based on test scores regression simple and of multiple regression where the value of a correlation coefficient ranges $0,9<\mathrm{r} \leq 1,0$ to showed that macrobenthhos abundance have a close relationship and have a correlation in which very real with type bottom substrate and organic matter in sediments.
\end{abstract}

Keywords : Bottom Substrate, Organic Matter, Macrobenthos, Sayung Estuary 


\section{Pendahuluan}

Muara sungai merupakan suatu perairan tertutup yang berada dibagian hilir sungai dan masih berhubungan dengan laut, sehingga memungkinkan terjadinya percampuran air tawar dan air laut (Rahman, 2009). Muara sungai Sayung merupakan salah satu muara sungai yang berada di Kabupaten Demak sebelah barat, dimana air muara sungai tersebut belum dimanfaatkan secara maksimal dan hanya dimanfaatkan untuk keperluan pertambakan didaerah hilir. Muara sungai Sayung terdapat di Desa Morosari yang terletak di Kecamatan Sayung, Kabupaten Demak. Muara sungai Sayung memiliki karakteristik tidak terlalu dalam dengan beragam populasi jenis biota yang ada.

Adapun tujuan penelitian ini adalah untuk mengetahui hubungan substrat dasar dan kandungan bahan organik dalam sedimen terhadap kelimpahan hewan makrobenthos dan untuk mengetahui kondisi lingkungan di Muara Sungai Sayung berdasarkan nilai indeks keanekaragaman dan indeks keseragaman. Sedangkan manfaat dari penelitian mengenai substrat dasar dan kandungan bahan organik serta kelimpahan hewan makrobenthos diharapkan mampu memberikan informasi mengenai kondisi lingkungan di perairan Muara Sungai Sayung tersebut. Sehingga dapat bermanfaat bagi pengelolaan dan pengembangan sumber daya pesisir dan laut khususnya kawasan perairan Muara Sungai Sayung, Demak. Penelitian ini dilaksanakan pada bulan April - Mei 2013 di Muara Sungai Sayung, Kabupaten Demak.

\section{Materi dan Metode Penelitian}

\section{A. Materi Penelitian}

Materi yang akan digunakan dalam penelitian ini adalah substrat dasar (sedimen) dan hewan makrobenthos. Pengambilan sampel hewan makrobenthos dan substrat dasar dan parameter kualitas air (fisika dan kimia perairan) dilakukan pada beberapa titik yang dianggap mampu mewakili secara keseluruhan.

\section{B. Metode Penelitian}

Metode yang akan digunakan dalam penelitian ini adalah metode purposive sampling dan metode dekriptif yang bersifat studi kasus. Menurut Fachrul (2007), Purposive sampling merupakan teknik pengambilan sampel yang digunakan apabila sampel yang akan diambil memilki pertimbangan tertentu. Sedangkan metode deskriptif yang bersifat studi kasus merupakan studi yang mempelajari obyek secara mendalam pada waktu, tempat, dan populasi yang terbatas, sehingga memberikan informasi situasi dan kondisi secara lokal dan hasilnya tidak berlaku untuk tempat dan waktu yang berbeda.

\section{Penentuan titik sampling}

Lokasi pengambilan sampel dilakukan dengan menentukan tiga stasiun sampling. Penentuan titik sampling didasarkan perbedaan substrat dasar dan salinitas pada ke tiga stasiun. Jarak antar stasiun kurang lebih $1 \mathrm{~km}$. Stasiun I adalah perairan Sungai Sayung yang bersubstrat lumpur dan salinitasnya sangat dipengaruhi oleh pasang surut air laut. Stasiun II adalah Muara sungai Sayung dimana salinitasnya 20\%o $30 \%$ dan substrat yang mendominasi adalah lumpur. Stasiun III daerah pantai disekitar muara sungai Sayung yang bersubstrat pasir berlumpur dan bersalinitas antara 25\% - 35\%. Pengambilan sampel dilakukan sebanyak tiga kali pengulangan dengan interval waktu pengambilan sampel setiap dua minggu sekali yaitu pada minggu pertama, minggu ketiga, dan minggu kelima.

\section{Teknik pengambilan sampel}

Pengambilan sampel hewan makrobenthos dan substrat dasar dengan menggunakan ekman grab yang memiliki luas bukaan $22,5 \mathrm{~cm} \times 22,5 \mathrm{~cm}$ x $30 \mathrm{~cm}$. Ekman grab digunakan karena biota yang akan diambil adalah biota yang hidup di permukaan dasar perairan dan kedalaman perairan berkisar $100 \mathrm{~cm}$. Sampel biota yang didapat kemudian disaring dengan sarigan berukuran $0,5 \mathrm{~mm}$ guna untuk memisahkan hewan makrobenthos dengan sedimen. Hewan makrobenthos yang telah tersaring dimasukan dalam botol sampel yang berisi formalin $4 \%$ dan cairan rose bengal yang berguna untuk mengawetkan dan memberi warna pada biota agar mudah ketika diidentifikasi. Setelah disimpan, sampel hewan makrobenthos dicuci dengan air tawar supaya bau formalin dan rose bangale hilang, setelah itu biota diidentifikasi dengan menggunakan mikroskop binokuler dan mengacu pada buku identifikasi hewan makrobenthos.

Sampel substrat dasar yang didapat kemudian di lakukan pengujian tekstur tanah dengan menggunakan metode pengayakan dan pemipetan berdasarkan Buchanan (1971) dalam BPAP (1994) dan memisahkan tekstur menjadi tiga fraksi yaitu Sand, Silt, dan Clay. Metode analisa pipet menggunakan pipet dalam pengindentifikasian besar butir dan penggunaan metode ini biasanya untuk sampel butir sedimen yang lebih halus ukurannya. Metode ayakan cocok digunakan untuk butiran-butiran yang lebih kasar. Metode ayakan dapat dibantu dengan menggunakan alat pengayakan seperti shiver shaker. Pengujian kandungan bahan organik dalam sedimen dengan menggunakan metode gravimetric berdasarkan dari BPAP (1994). Dalam metode ini semua bahan organik dianggap volatile (menguap) bila dibakar pada suhu $550 \square \mathrm{C}$ selama 4 jam. 


\section{Pengolahan data}

a. Menghitung kelimpahan individu

Komposisi individu hewan makrobenthos menggambarkan jenis yang terdapat dilingkungannya. Kelimpahan jenis dihitung berdasarkan jumlah individu per satuan volume (ind $/ \mathrm{m}^{3}$ ).

Dengan :

$$
X=\frac{\sum_{i=1}^{n} X i}{n}
$$

$\mathrm{X}=$ rata-rata jumlah individu pada pengambilan contoh sebnyak $\mathrm{n}$ kali

$\mathrm{Xi}=$ jumlah individu pada pengambilan contoh ke-i

$\mathrm{n}=$ jumlah pengambilan contoh

b. Menghitung keanekaragaman jenis (H')

Keanekaragaman menunjukkan keberagaman jenis dan merupakan suatu ciri khas struktur komunitas. Keanekaragaman ditentikan berdasarkan indeks keanekaragaman Shannon-Wiener dengan rumus sebagai berikut:

$$
H=-\sum_{i=1}^{S} P i \ln P i
$$

Dengan :

$\mathrm{Pi} \quad=$ Jumlah individu masing-masing jenis $(\mathrm{i}=1,2,3, \ldots, \mathrm{dst})$

$\mathrm{S} \quad=$ Jumlah jenis

$\mathrm{H} \quad=$ Penduga keragaman populasi

Wilhm (1975) dalam Fachrul (2007) kriteria yang digunakan untuk menggambarkan keanekaragaman Shannon-Wiener yaitu :

$\mathrm{H}^{\prime} \quad=<1$, keanekaragaman rendah

$\mathrm{H}^{\star} \quad=1-3$, keanekaragaman tergolong sedang

H' = $\quad=3$, keanekaragaman tergolong tinggi

c. Menghitung indeks keseragaman jenis (e)

Indeks keseragaman diguakan untuk mengetahui seberapa besar kesamaan penyebaran jumlah idividu tiap jenis spesies, caranya dengan membandingkan indeks keanekaragaman dengan nilai maksimumnya dengan rumus :

$$
e=\frac{H^{\prime}}{\text { Hmaksimum }}
$$

Dengan :

$$
\begin{array}{ll}
\mathrm{e} & =\text { indeks keseragaman } \\
\mathrm{H}, & =\text { indeks keanekaragaman } \\
\text { Hmaksimal } & =\ln \mathrm{S}
\end{array}
$$

Indeks keseragaman berkisar antara 0 - 1, bila indeks keseragaman kurang dari 0,4 maka ekosistem tersebut berada dalam kondisi tertekan dan mempunyai keseragam rendah. Jika indeks keseragaman antara 0,4-0,6 maka ekosistem tersebut dalam kondisi kurang stabil dan memiliki keseragaman yang sedang. Jika indeks keseragamannya $>0,6$ maka ekosistem tersebut dalam kondisi stabil serta memiliki keseragaman yang tinggi.

\section{Analisa data}

Data yang telah didapat kemudian dianalisa dengan dua pengujian, yaitu regresi linier sederhana dan regresi berganda. Menurut Kurniawan (2008) regresi linier merupakan metode statistik yang digunakan untuk membentuk model hubungan antara variable terikat (dependen; Y) dengan satu atau lebih variable bebas (independen; X). Apabila banyaknya variable bebas hanya ada satu disebut regresi linier sederhana, sedangkan apabila terdapat lebih dari satu variable bebas disebut regresi linier berganda. Uji regresi linier sederhana digunakan untuk menentukan hubungan antara substrat (substrat lumpur) dengan kandungan bahan organik dalam sedimen, sedangkan uji regresi berganda digunakan untuk mengetahui hubungan substrat dasar dan kandungan bahan organik dalam sedimen dengan kelimpahan hewan makrobenthos. Data yang digunakan untuk analisa adalah hasil rata-rata dari hasil pengulangan sampling pada setiap stasiunnya.

\section{Hasil dan Pembahasan \\ Hasil \\ Deskripsi Lokasi}

Muara sungai Sayung tepatnya di Desa Morosari Kecamatan Sayung, Kabupaten Demak sebelah barat, dimana air muara sungai tersebut belum dimanfaatkan secara maksimal dan hanya dimanfaatkan untuk keperluan pertambakan didaerah hilir. Muara sungai Sayung memiliki lebar kurang lebih 40 meter dengan 
kedalaman sekitar $90-130 \mathrm{~cm}$. Sepanjang aliran muara sungai Sayung merupakan kawasan rumah padat penduduk, dimana setiap tahunnya terjadi rob yang diakibatkan adanya proses sedimentasi di perairan Sayung Kabupaten Demak.

Lokasi sampling penelitian ini dibagi menjadi tiga stasiun. Stasiun pertama merupakan daerah Sungai Sayung, stasiun kedua daerah Muara Sungai Sayung, dan stasiun ketiga adalah daerah pantai disekitar perairan Muara Sungai Sayung. Pada setiap stasiun ditentukan letak koordinat lintang selatan dan bujur timur. Stasiun I terletak pada koordinat $06^{\circ} 56^{\prime} 07,4^{\prime \prime}$ LS dan $110^{\circ} 29^{\prime} 52,1^{\prime \prime}$ BT dimana merupakan perairan sungai yang berada di sekitar pertambakan dan banyak ditumbuhi tanaman air. Stasiun II berada pada koordinat $06^{\circ} 55^{\prime} 27,1^{\prime \prime}$ LS dan $110^{\circ} 28^{\prime} 45,1^{\prime \prime}$ BT dimana merupakan daerah pemukiman, terdapat banyak tumbuhan mangrove, dan menjadi tempat penambatan dan jalur kapal-kapal nelayan. Stasiun III terletak pada koordinat $06^{\circ} 55^{\prime} 15,8^{\prime \prime}$ LS dan $110^{\circ} 28^{\prime} 34,2^{\prime \prime}$ BT yang merupakan kawasan pariwisata pantai di sekitar Muara Sungai Sayung.

\section{Tekstur Substrat Dasar}

Hasil pengujian komposisi substrat dasar di Muara Sungai Sayung tersaji dalam Tabel 1 berikut ini: Tabel 1. Hasil Uji Tekstur Sedimen Muara Sungai Sayung, Kabupaten Demak

\begin{tabular}{ccccc}
\hline Stasiun & \multicolumn{3}{c}{ Presentase (\%) } & Kriteria \\
\cline { 2 - 4 } & \% SAND (pasir) & \% SILT (lumpur) & \% CLAY (lempung) & \\
\hline I & 1,18 & 84,44 & 14,38 & lumpur berlempung \\
II & 9,59 & 78,00 & 12,41 & lumpur berlempung \\
III & 65,04 & 19,33 & 15,62 & pasir berlumpur \\
\hline
\end{tabular}

Hasil uji tekstur sedimen Muara Sungai Sayung menunjukkan bahwa pada stasiun I dan II memiliki kriteria lumpur berlempung, sedangkan pada stasiun III memiliki kriteria pasir berlumpur.

\section{Kandungan Bahan Organik dalam Sedimen} ini:

Hasil pengujian bahan organik dalam sedimen di Muara Sungai Sayung tersaji dalam Tabel 2 berikut

Tabel 2. Hasil Uji Bahan Organik dalam Sedimen Muara Sungai Sayung

\begin{tabular}{ccc}
\hline Stasiun & Kandungan Bahan Organik Dalam Sedimen $(\%)$ & Kriteria \\
\hline I & 11,95 & Sedang \\
II & 13,29 & Sedang \\
III & 8,07 & Sedang \\
\hline
\end{tabular}

Kisaran * = Reynold (1983) dalam Rosmarkam dan Yuwono (2002)

Dari hasil pengujian diatas dapat dilihat bahwa pada tabel diatas kandungan bahan organik dalam sedimen di Muara Sungai Sayung, Demak yang di ukur selama 1 bulan memiliki nilai yang bervariasi dimana menurut Reynold (1983) dalam Rosmarkam dan Yuwono (2002) bahwa nilai tersebut masuk dalam kriteria sedang.

Uji Regresi Linier Sederhana Antara Substrat Dasar dan Kandungan Bahan Organik dalam Sedimen

Pengujian regresi linier sederhana digunakan untuk mengetahui seberapa besar hubungan antara dua variabel, dimana sebagai variabel bebas $(\mathrm{X})$ adalah substrat dasar dan sebagai variabel terikat $(\mathrm{Y})$ adalah kandungan bahan organik dalam sedimen. Substrat dasar yang diujikan dalam uji regresi tersebut adalah substrat lumpur, karena fraksi lumpur lebih besar nilainya daripada nilai fraksi pasir maupun fraksi lumpur. Menurut Hasan (2003), keeratan hubungan antar variabel dapat dilihat dari nilai korelasinya (r). Apabila $r$ bernilai -1 maka keertana hubungan yang ada negatif, $r$ bernilai 0 (nol) maka tidak ada hubungan sama sekali, dan jika $\mathrm{r}$ bernilai 1 maka hubungan yang ada positif atau sangat kuat. Hasil analisis regresi linier sederhana pada penelitian ini menunjukkan bahwa kandungan bahan organik dalam sedimen memiliki hubungan yang kuat sekali dengan tipe substrat dasar, dimana nilai $r$ yang didapatkan berkisar $0,90<r \leq 1,00$ dan nilai $r$ square (determinasi) sebesar 0,889 yang berarti bahwa kandungan bahan organik dalam sedimen dipengaruhi oleh substrat dasar sebesar $88,9 \%$ dan sisanya dipengaruhi oleh faktor lainnya. 
Komposisi dan Kelimpahan (Ind/ $\mathbf{m}^{3}$ ), Indeks Keanekaragaman (H'), Indeks Keseragaman (E), dan Indeks Dominasi (C) Hewan Makrobenthos di Muara Sungai Sayung, Kabupaten Demak

Hewan makrobenthos yang diperoleh dalam penelitian ini terdiri atas 3 kelas yang terbagi dalam 13 jenis, yaitu Gastropoda 4 jenis, Bivalvia 5 jenis, dan Polychaeta 4 jenis. Nilai kelimpahan (Ind/ $/ \mathrm{m}^{3}$ ) hewan markrobenthos tersaji pada Tabel 3 berikut ini :

Tabel 3. Komposisi dan Kelimpahan Hewan Makrobenthos $\left(\mathrm{ind} / \mathrm{m}^{3}\right.$ ) di Muara Sungai Sayung, Kabupaten Demak

\begin{tabular}{|c|c|c|c|c|c|c|c|c|c|}
\hline \multirow{3}{*}{ Biota } & \multicolumn{9}{|c|}{ Stasiun } \\
\hline & \multicolumn{3}{|c|}{ I } & \multicolumn{3}{|c|}{ II } & \multicolumn{3}{|c|}{ III } \\
\hline & 1 & 2 & 3 & 1 & 2 & 3 & 1 & 2 & 3 \\
\hline \multicolumn{10}{|l|}{ Gastropoda } \\
\hline Melanoides sp. & 15 & 27 & 45 & 0 & 0 & 0 & 0 & 0 & 0 \\
\hline Cerithidea sp. & 0 & 0 & 0 & 0 & 0 & 0 & 2 & 1 & 2 \\
\hline Turricula sp. & 0 & 0 & 0 & 0 & 0 & 0 & 0 & 0 & 1 \\
\hline Nassarius sp. & 0 & 0 & 0 & 0 & 0 & 0 & 1 & 0 & 1 \\
\hline \multicolumn{10}{|l|}{ Bivalvia } \\
\hline Sphaerium sp. & 1 & 0 & 0 & 0 & 0 & 0 & 0 & 0 & 0 \\
\hline Arcuatula sp. & 0 & 0 & 0 & 150 & 267 & 215 & 0 & 0 & 0 \\
\hline Perna sp. & 0 & 0 & 0 & 0 & 0 & 0 & 7 & 2 & 11 \\
\hline Marcia sp. & 0 & 0 & 0 & 0 & 0 & 0 & 0 & 0 & 1 \\
\hline Anadara sp. & 0 & 0 & 0 & 0 & 0 & 0 & 1 & 0 & 0 \\
\hline \multicolumn{10}{|l|}{ Polychaeta } \\
\hline Nereis sp. & 7 & 21 & 5 & 0 & 0 & 0 & 6 & 0 & 2 \\
\hline Goniada sp. & 0 & 0 & 0 & 0 & 0 & 0 & 0 & 3 & 4 \\
\hline Glycerida sp. & 0 & 0 & 0 & 0 & 0 & 0 & 0 & 1 & 0 \\
\hline Notomastus sp. & 0 & 0 & 0 & 6 & 9 & 5 & 2 & 0 & 1 \\
\hline Jumlah & 23 & 48 & 50 & 156 & 276 & 220 & 19 & 7 & 23 \\
\hline Total & & 121 & & & 652 & & & 49 & \\
\hline Kelimpahan (ind $/ \mathrm{m}^{3}$ ) & & 889 & & & 4829 & & & 363 & \\
\hline
\end{tabular}

Berdasarkan tabel diatas terlihat kelimpahan terbesar adalah stasiun II sebesar $4.829\left(\mathrm{ind} / \mathrm{m}^{3}\right)$, stasiun I sebesar $889\left(\mathrm{ind} / \mathrm{m}^{3}\right)$, dan stasiun III sebesar $363\left(\mathrm{ind} / \mathrm{m}^{3}\right)$. Biota yang paling banyak ditemukan dari ketiga stasiun tersebut adalah jenis Melanoides sp. dan Arcuatula sp. Nilai indeks keanekaragaman (H'), indeks keseragaman (e), dan indeks dominasi (C) pada tiap-tiap stasiun dapat dilihat pada Tabel 4 di bawah ini.

Tabel 4. Indeks Keanekaragaman (H') dan Indeks Keseragaman (e) Hewan Makrobenthos di Muara Sungai Sayung,Demak

\begin{tabular}{lcccc}
\hline & Indeks & \multicolumn{3}{c}{ Stasiun } \\
\cline { 2 - 4 } & & I & II & III \\
\hline Keanekaragaman $\left(\mathrm{H}^{\prime}\right)$ & 0,63 & 0,13 & 1,79 \\
Keseragaman $(\mathrm{e})$ & 0,57 & 0,19 & 0,78 \\
\hline
\end{tabular}

Indeks keanekaragaman tertinggi terdapat pada stasiun III yaitu 1,79 dan terendah pada stasiun II sebesar 0,13. Nilai indeks keseragaman pada stasiun I dan III mendekati nilai 1, sedangkan pada stasiun II masih dibawah nilai nol.

\section{Uji Regresi Linier Berganda Antara Substrat Dasar dan Kandungan Bahan Organik dalam Sedimen} dengan Kelimpahan Hewan Makrobenthos

Pengujian regresi linier berganda digunakan untuk mengetahui hubungan antara satu variabel terikat (Y) dengan variabel bebas $(\mathrm{X})$ yang lebih dari satu. Substrat dasar $\left(\mathrm{X}_{1}\right)$ dan kandungan bahan organik dalam sedimen $\left(\mathrm{X}_{2}\right)$ sebagai variabel bebas dan kelimpahan hewan makrobenthos sebagai variabel terikat (Y). Hasil uji regresi berganda antara substrat dasar dan kandungan bahan organik dalam sedimen dengan kelimpahan hewan makrobenthos didapatkan nilai korelasi (r) sebesar 1 dimana keeratan hubungan kedua variabel sangat kuat, karena nilai $\mathrm{r}$ bernilai 1 dan nilai determinasi ( $\mathrm{r}$ square) yang didapat adalah 1,00 yang berarti bahwa 
kandungan bahan organik dalam sedimen dan substrat dasar sangat berpengaruh terhadap kelimpahan dan penyebaran hewan makrobenthos dan hubungan tersebut sangat nyata.

\section{Parameter Kualitas Air}

Hasil pengukuran kualitas air (parameter fisika dan kimia) dapat digunakan sebagai salah satu pertimbangan terhadap penyebaran serta kelimpahan hewan makrobenthos yang ada di Muara Sungai Sayung Kabupaten Demak. Data parameter kualitas air tersaji dalam Tabel 5 berikut ini:

Tabel 5. Hasil Pengukuran Parameter Kualitas Air di Muara Sungai Sayung, Demak

\begin{tabular}{|c|c|c|c|c|}
\hline \multirow[t]{2}{*}{ Parameter Kualitas Air } & \multicolumn{3}{|c|}{ Stasiun } & \multirow[t]{2}{*}{ Pustaka } \\
\hline & I & II & III & \\
\hline Kedalaman $(\mathrm{cm})$ & 102 & 98 & 128 & $100-125 \mathrm{~cm}$ (Nybakken, 1992) \\
\hline Kecerahan $(\mathrm{cm})$ & 24,55 & 21,95 & 31,78 & $15-150 \mathrm{~cm}$ (Nybakken, 1992) \\
\hline Kecepatan Arus (m/s) & 1,02 & 0,28 & 0,56 & - \\
\hline Salinitas $(\%)$ & 0 & 22,56 & 28,89 & $\begin{array}{c}\text { Payau dan laut } 5 \% \text { \%o } 30 \% \text {, Tawar }<5 \% \text { o } \\
\text { ( Rahman, 2009) }\end{array}$ \\
\hline Suhu $\left({ }^{\circ} \mathrm{C}\right)$ & 29,09 & 30,57 & 30,81 & $20^{\circ} \mathrm{C}-30^{\circ} \mathrm{C}($ Rahman, 2009$)$ \\
\hline $\mathrm{DO}(\mathrm{mg} / \mathrm{l})$ & 4,48 & 5,06 & 5,13 & >3 (MNLH, 2004 dalam Hanifah,2007) \\
\hline $\mathrm{pH}$ & 7 & 7 & 8 & $7-8$ (Rahman, 2009) \\
\hline
\end{tabular}

\section{Pembahasan}

Hubungan Substrat Dasar dan Kandungan Bahan Organik dalam Sedimen

Substrat dasar berkaitan erat dengan fraksi butiran sedimen. Stasiun I dan II lebih didominasi oleh substrat berupa lumpur dengan presentase lumpur 78,00\% - 84,44\%, sedangkan pada stasiun III berupa pasir berlumpur dengan presentase fraksi pasir sebanyak $65,04 \%$ dan fraksi lumpur berkisar antara 19,33\%. Secara keseluruhan (visual) tekstur sedimen diperairan Muara Sungai Sayung Demak selama penelitian digolongkan kedalam jenis lumpur berlempung. Selama penelitian kecepatan arus di perairan Muara Sungai Sayung memiliki kecepatan arus sedang hingga lambat. Sehingga sebagian besar daerah di sekitar muara didominasi oleh substrat berlumpur. Hal ini diperkuat dengan pendapat Nybakken (1982) bahwa pada muara sungai dengan arus yang lemah jenis substratnya adalah lumpur dan liat, apabila arusnya kuat akan banyak ditemui substrat berpasir karena hanya partikel yang berukuran besar lebih cepat mengendap dari pada partikel yang lebih kecil.

Nilai kandungan bahan organik pada masing-masing stasiun cenderung bervariasi dan erat kaitannya dengan jenis substrat. Pada stasiun I dan II kandungan bahan organik selama penelitian berkisar 11,95\% $13,29 \%$, sedangkan pada stasiun III berkisar 8,07\% dimana ketiga stasiun tersebut masuk dalam kriteria sedang. Perbedaan kandungan bahan organik dalam sedimen dikarenakan substrat dasar pada stasiun I dan II didominasi oleh lumpur dan stasiun III pasir berlumpur. Kemampuan lumpur untuk menyimpan bahan organik lebih besar daripada pasir dikarenakan substrat lumpur memiliki pori-pori yang lebih rapat sehingga bahan organik lebih mudah mengendap dibandingkan substrat pasir yang partikel dan pori-porinya lebih besar yang menyebabkan bahan organik mudah terbawa arus. Hal ini sesuai dengan pendapat EPA (1985) dalam Hanifah (2007), bahwa kandungan bahan organik dalam sedimen sangat berhubungan dengan jenis atau tesktur sedimen, tesktur yang berbeda mempunyai kandungan bahan organik yang berbeda pula.

Berdasarkan nilai uji regresi linier sederhana antara substrat dasar dan kandungan bahan organik dalam sedimen menunjukkan hubungan yang sangat kuat, dimana nilai korelasi (r) yang didapatkan sebesar 0,943 dan nilai determinasi $\left(\mathrm{r}^{2}\right)$ sebesar 0,889 yang menunjukkan bahwa substrat dasar mempengaruhi kandungan bahan organik dalam sedimen sebesar $88,9 \%$ dan sisanya dipengaruhi oleh faktor lain.

\section{Hubungan Substrat Dasar dan Kandungan Bahan Organik dalam Sedimen dengan Kelimpahan Makrobethos}

Berdasarkan hasil penelitian hewan makrobenthos dari kelas Polychaeta banyak ditemukan pada stasiun I dan II yang memiliki substrat lumpur berlempung dengan kandungan bahan organik yang tinggi. Kelas Polychaeta lebih menyukai tempat dengan tekstur yang lunak seperti lumpur, karena lumpur memudahkan hewan Polychaeta untuk membenamkan diri dalam tanah. Hal ini diperkuat dengan pernyataan Reish (1979) dalam Zahidin (2008) bahwa Polychaeta banyak dijumpai pada substrat berlumpur, kemudian pasir sangat halus, dan terakhir pasir halus. Pernyataan ini juga didukung oleh Devaney et al, (1987) dalam Hardiyanto (2010) bahwa lumpur menyediakan partikel-partikel organik yang akan menjadi makanan bagi Capitellidae. Bahan organik menjadi sumber makanan yang sangat penting bagi biota-biota dari kelas Polychaeta. Tinggi rendahnya kandungan bahan organik dalam sedimen akan berpengaruh terhadap kehidupan biota tersebut.

Hewan makrobenthos dari kelas Bivalvia banyak ditemukan pada substrat berlumpur hingga pasir berlumpur. Jenis Arcuatula sp. banyak ditemukan di daerah lumpur berlempung dengan kandungan bahan 
organik yang tinggi. Anadara sp, Perna sp. dan Marcia sp. banyak ditemukan di substrat pasir belumpur. Pada dasarnya ketiga jenis tersebut memiliki habitat dengan tekstur berpasir atau sedikit berlumpur. Sehingga substrat dasar di lokasi penelitian sesuai untuk ketiga jenis biota tersebut. Cerithidea sp. merupakan jenis gastropoda yang banyak ditemukan di daerah pasir berlumpur yang memiliki adaptasi yang baik dengan jenis substrat pasir, lumpur, hingga pasir berlumpur. Pada tekstur substrat dasar pasir berlumpur dan lumpur berlempung memiliki kandungan bahan organik yang tinggi dari pada substrat pasir, sehingga banyak jenis gastropoda dan bivalvia yang melimpah jumlahnya pada substrat pasir berlumpur dan lumpur berlempung, karena semakin halus tekstur substrat dasar maka kemampuan dalam menjebak bahan organik akan semakin besar. Hal ini menunjukkan bahwa ukuran butir sedimen turut mempengaruhi kandungan bahan organik dalam sedimen.

Hasil uji regresi berganda antara substrat dasar dan kandungan bahan organik dalam sedimen dengan kelimpahan hewan makrobenthos didapatkan nilai koefisien korelasi (r) yaitu sebesar 1 yang menggambarkan bahwa hubungan antara ketiga variabel sempurna dan saling berkaitan satu dengan lainnya. Hal ini sesuai dengan pendapat Hasan (2003), apabila nilai korelasi (r) lebih 1 maka keeratan hubungan semua variable sempurna dan korelasi yang ada sangat nyata.

Kelimpahan $\left(\mathrm{Ind} / \mathrm{m}^{3}\right)$ Hewan Makrobenthos di Muara Sungai Sayung, Kabupaten Demak

Kelimpahan hewan makrobenthos tertinggi dijumpai pada stasiun I dan II, dimana kelimpahan stasiun I sebesar $889\left(\mathrm{ind} / \mathrm{m}^{3}\right)$ dan stasiun II berkisar $4.829\left(\mathrm{ind} / \mathrm{m}^{3}\right)$. Tingginya kelimpahan pada dua stasiun tersebut didukung oleh tingginya kandungan bahan organik dalam sedimen dan mendapat sumbangan bahan organik yang berasal dari vegetasi tumbuhan di sepanjang aliran sungai dan muara sungai Sayung dan limbah organik yang berasal dari limbah rumah tangga. Kelimpahan hewan makrobenthos pada stasiun III kecil dikarenakan bahan organik yang masuk ke perairan pantai tersebar menuju laut, sehingga persebaran hewan makrobenthos tidak sama. Bahan organik yang berasal dari daratan dan muara akan menyebar sesampainya di laut, sehingga kelimpahan hewan makrobenthos yang ada di perairan pantai sekitar muara sungai Sayung tidak merata. APHA (1992) dalam Amin (2012) menyatakan bahwa selain dipengaruhi oleh kandungan bahan organik dalam sedimen, kelimpahan hewan makrobenthos pada suatu perairan sangat dipengaruhi pula oleh berbagai faktor lingkungan baik biotik yang meliputi hubungan antar jenis yang berlaku sebagai kompetitor, predator atau parasit. maupun abiotik yang terdiri dari faktor fisika-kimia lingkungan seperti suhu, kedalaman, kecerahan, $\mathrm{pH}$, serta besar sumber bahan organik.

Indeks Keanekaragaman (H') dan Indeks Keseragaman (E) Hewan Makrobenthos di Muara Sungai Sayung, Demak

Stasiun I memiliki nilai keanekaragaman sebesar 0,63 dimana nilai tersebut kurang dari 1 yang berarti nilai keanekaragamannya rendah. Hal ini sesuai dengan pendapat Wilhm (1975) dalam Fachrul (2007) bahwa apabila nilai $\mathrm{H}^{\prime}<1$ maka keanekaragamnnya rendah, jumlah spesiesnya tidak seragam, dan terdapat spesies yang mendominasi. Nilai indeks keseragaman pada stasiun I $0,57 \quad(0,4 \leq \mathrm{e} \leq 0,6)$ yang berarti keseragamannya sedang dengan persebaran spesiesnya tidak sama dan keadaan ekosistemnya kurang stabil. Menurut Krebs (1989) dalam Irawan (2008), Jika indeks keseragaman antara 0,4 - 0,6 maka ekosistem tersebut dalam kondisi kurang stabil dan memiliki keseragaman yang sedang dan terdapat spesies yang mendominasi. Hal ini terbukti dengan melimpahnya jenis Melanoides sp. daripada kelimpahan hewan makrobenthos yang lainnya. Dilihat dari nilai indeks keanekaragam dan keseragaman yang rendah dan terdapat jenis yang mendominasi mengindikasikan bahwa kondisi lingkungan pada stasiun I tidak stabil dan rawan untuk kehidupan biota yang ada didalamnya.

Stasiun II memiliki nilai keanekaragaman sebesar 0,13 yang termasuk dalam kategori keanekaragaman rendah, karena $\mathrm{H}^{\prime}<1$ yang menurut Wilhm (1975) dalam Fachrul (2007) nilai indeks keanekaragaman berdasarkan Shannon-Wiener artinya jumlah individu tak seragam dan ada salah satu jenis yang mendominasi. Hal ini terbukti pada stasiun II nilai keseragaman yang rendah yaitu 0,19 dan hanya ditemukan Arcuatula sp. yang jumlahnya sangat melimpah. Nilai keanekaragaman dan keseragamnya yang rendah mengindikasikan bahwa perairan dalam kondisi tertekan dan rawan terjadinya penurunan pada fungsi ekosistemnya.

Stasiun III nilai indeks keanekaragaman tergolong sedang yaitu 1,79 dan indeks keseragaman 0,78 yang tergolong tinggi. Berdasarkan nilai tersebut terlihat bahwa kondisi ekosistemnya stabil dan tidak terdapat spesies yang mendominasi dengan kondisi lingkungan yang cukup layak untuk kehidupan hewan makrobenthos. Hal ini sesuai dengan pendapat Irma (2001), apabila nilai indeks keseragaman $0,6 \leq \mathrm{E} \leq 1,0$ maka keseragamannya tinggi diperkuat dengan pendapat Wilhm (1975) dalam Fachrul (2007) mengenai kriteria nilai indeks keanekaragaman yang kisaran $\mathrm{H}^{\prime}$ antara $1-3$ maka keanekaragaman yang ada sedang dan kondisi lingkungannya stabil.

\section{Parameter Kualitas Air}

Berdasarkan hasil penelitian kedalaman rata-rata ketiga stasiun berkisar $98-128 \mathrm{~cm}$. Menurut Hanifah (2007), kedalaman pada suatu perairan berpengaruh terhadap berbagai faktor lingkungan seperti suhu dan kecerahan yang tentunya akan mempengaruhi penyebaran dan jumlah dari hewan makrobenthos. 
Kandungan oksigen terlarut (DO) dari ketiga stasiun tersebut yang paling rendah adalah stasiun I yaitu 4,48 mg/l, sedangkan stasiun II 5,06 mg/l dan stasiun III yaitu 5,13 mg/l tergolong tinggi. Kisaran oksigen terlarut pada perairan Muara Sungai Sayung Demak masih berada pada kisaran normal dimana masih dapat menopang kehidupan hewan makrobenthos sesuai dengan baku mutu kualitas air untuk biota yang ditetapkan Menteri Negara Lingkungan Hidup yaitu > 3 mg/l (MNLH, 2004 dalam Hanifah , 2007).

Pengukuran suhu perairan muara sungai Sayung Demak selama waktu penelitian berkisar antara $29,09-30,81^{\circ} \mathrm{C}$. Menurut Rahman (2009), suhu optimum bagi perkembangan hewan makrobenthos berkisar antara $20-30^{\circ} \mathrm{C}$, pada kisaran suhu yang tinggi sekitar $33-50^{\circ} \mathrm{C}$ menyebabkan terjadinya gangguan perkembangan daur hidup, dan penurunan suhu dapat menyebabkan perpanjangan waktu pergantian generasi. Suhu yang tinggi akan berakibat menurunnya kadar oksigen terlarut dalam perairan.

Salinitas di perairan muara sungai Sayung selama penelitian berkisar antara $0 \%-28,89 \%$. Menurut Yuniar (2012) bahwa salinitas yang ideal untuk pertumbuhan biota makrobenthos adalah $26 \%$ - $37 \%$. Distribusi Polychaeta dapat dipengaruhi oleh perubahan salinitas terutama di daerah muara sungai, dimana perubahan salinitas yang besar akan mengakibatkan jumlah hewan makrobenthos berkurang. Menurut Burkovskiy and Stolyarov (1996) dalam Henni (2007) bahwa famili Nereidae mampu hidup pada kisaran salinitas antara $6 \%$ - $24 \%$ sedangkan Famili Capitelidae mampu hidup pada salinitas air hingga 38 \%o, salinitas optimum bagi Gastropoda $2 \%-32 \%$, dan Bivalvia berkisar $2 \%-36 \%$. Selama penelitian jenis Polychaeta yang banyak ditemukan adalah Nereis sp. dan Notomastus sp. dimana kedua jenis tersebut menyukai habitat dengan salinitas yang tinggi. Stasiun II dan III memiliki kisaran salinitas 22,56 \%o 28,89\%, banyak ditemukan Polychaeta jenis Notomastus sp.dan Nereis sp.. Namun tidak menutup kemungkinan jenis Nereidae dapat melimpah jumlahnya pada kondisi salinitas yang rendah hingga tinggi. Hal ini terbukti dengan banyaknya Nereis sp. pada stasiun I dimana kemungkinan Nereid yang ada terbawa pada saat air pasang yang sampai ke sungai. Sesuai dengan pernyataan Beessley (2000) dalam Ni'amillah (2012), bahwa famili Nereidae dan Capitellidae tergolong dalam jenis organisme Euryhaline yang dapat ditemukan dalam kisaran salinitas yang rendah sampai paling tinggi sekalipun.

Kecerahan perairan muara sungai Sayung Demak selama waktu penelitian berkisar antara 21,95 - 31,78 $\mathrm{cm}$. Hasil pengukuran kecerahan menunjukkan bahwa stasiun II (daerah Muara Sungai Sayung) memiliki nilai kecerahan terendah yaitu $21,95 \mathrm{~cm}$ dibandingkan dengan stasiun I yaitu $24,55 \mathrm{~cm}$ dan stasiun III 31,78 $\mathrm{cm}$. Kecerahan di muara sungai Sayung rendah dikarenakan terjadi sedimentasi dari suplai air sungai yang membawa partikel-partikel lumpur dan bahan organik dari daratan sehingga apabila terjadi pengadukan, maka partikel-partikel tersebut akan terangkat dan mengakibatkan perairan menjadi keruh.

pH atau derajat keasaman merupakan suatu ukuran dari konsentrasi ion hydrogen. Kondisi tersebut akan menunjukkan suasana air dalam kondisi asam atau basa. Nilai $\mathrm{pH}$ selama penelitian berkisar $7-8$. Kisaran nilai ini masih sesuai dengan standar baku kualitas air untuk biota perairan. Dalam keputusan Menteri Negara Lingkungan Hidup (2004) dalam Hanifah (2007) kisaran $\mathrm{pH}$ normal perairan yang dapat menompang kehidupan organisme perairan adalah 6,50-8,50.

Kecepatan arus tertinggi terdapat pada stasiun I sebesar $1,02 \mathrm{~m} / \mathrm{s}$ dan yang terendah terdapat pada stasiun II yaitu $0,28 \mathrm{~m} / \mathrm{s}$. Kecepatan arus selama penelitian tergolong sedang ke cepat, hal ini dikarenakan sebelum dilakukan pengamatan terjadi banjir di aliran sungai Sayung yang mengakibatkan arusnya tergolong cepat. Menurut Zulfiandi (2012), kecepatan arus antara 0,3-0,39 $\mathrm{m} / \mathrm{s}$ termasuk dalam kategori berarus sedang dan masih dibawah ambang batas bagi kehidupan hewan makrobenthos. Kecepatan arus juga akan mempengaruhi distribusi sedimen yang nantinya akan membentuk substrat dasar yang akan menjadi habitat bagi hewan makrobenthos yang ada di perairan.

\section{Kesimpulan}

Kesimpulan yang di dapatkan dari penelitian diatas adalah

1. Berdasarkan nilai uji regresi linier sederhana dan regresi linier berganda dimana nilai $r$ berkisar $0,90<r$ $\leq 1,00$ maka dapat disimpulkan bahwa kelimpahan hewan makrobenthos memiliki hubungan yang sangat kuat dengan kandungan bahan organik dalam sedimen dan substrat dasar;

2. Pada stasiun I dan II nilai indeks keanekaragaman masing-masing 0,63 dan 0,13 dengan nilai indeks keseragaman sebesar 0,57 dan 0,19 . Nilai keanekaragaman yang rendah menandakan bahwa kondisi lingkungannya sudah tidak layak bagi kehidupan biota yang ada didalamnya. Nilai keseragaman yang rendah menunjukkan bahwa kondisi ekosistemnya tidak stabil dan rawan akan terjadinya penurunan pada fungsi ekosistemnya.

\section{Ucapan Terima Kasih}

Ucapan terima kasih ditujukan kepada Bapak Dr. Ir. Max Rudolf Muskananfola, MSc dan Ibu Ir. Ruswahyuni, M.Sc atas bimbingannya dalam penyusunan jurnal penelitian ini. 


\section{DAFTAR PUSTAKA}

Amin, B. 2012. Kandungan Bahan Organik, Sedimen, dan Kelimpahan Makrozoobenthos Sebagai Indikator Pencemaran Perairan Pantai Tanjung Uban Kepulauan Riau. Universitas Riau, Pekanbaru.

BPAP. 1994. Pendoman Analisis Kualitas Air dan Tanah Sedimen Periaran Payau. Direktorat Jendral Perikanan, Jepara.

Effendi, H. 2000. Telaah Kualitas Air : Bagi Pengelolaan Sumberdaya Lingkungan Perairan. Kanisius, Yogyakarta.

Fachrul, M.F. 2007. Metode Sampling Bioekologi. Bumi Aksara, Jakarta.

Hanifah, M.Z.N. 2007. Kualitas Fisika-Kimia Sedimen Serta Hubungannya Terhadap Struktur Komunitas Makrozoobenthos di Estuari Percut Sei Tuan Kabupaten Deli Serdang. [Tesis]. Sekolah Pascasarjana, Institut Pertanian Bogor, Bogor, 95 hlm.

Hardiyanto. 2010. Biologi, Ekologi, dan Peranan Suku Capitellidae Grube 1862 (Annelida : Polychaeta). Oseana. 35( 3):29-28.

Hasan, M.I. 2003. Pokok-Pokok Materi Statistik 1 (Deskrisi Deskriptif). Ed. 2. Bumi Aksara, Jakarta.

Henni, W. 2007. Kajian Kualitas Perairan di Pantai Kota Bandar Lampung Berdasarkan Komunitas Hewan Makrobenthos. [Tesis]. Program Pascasarjana, Universitas Diponegoro, Semarang, 86 hlm.

Hynes, H.B.N. 1972. The Ecology of Running Water. Universitas Toronto Press, Canada.

Irawan, I. 2008. Struktur Kominutas Moluska (Gastropoda dan Bivalvia) Serta Distribusi di Pulau Burung dan Pulau Tikus, Gugusan Pulau Pari, Kepulauan Seribu. IPB, Bogor.

Irma, A.S. 2001. Struktur Komunitas Makrozoobenthos di Sedimen Dasar Sungai Cileungsi - Bekasi, Kabupaten Bogor dan Bekasi, Jawa Barat. IPB, Bogor, 53 hlm.

Kurniawan, D. 2008. Regresi Linier. http://www. ineddeni.wordpress.com (20 Mei 2013).

Ni'amillah. 2012. Struktur Komunitas Makrobenthos Polychaeta di Ekosistem Mangrove Desa Bedono Kecamatan Sayung, Kabupaten Demak. Journal of Marine Research. Universitas Diponegoro, Semarang, 1(1):54-61.

Nybakken, J.W. 1982. Biologi Laut suatu Pendekatan Ekologis. Diterjemahkan oleh H.M. Eidman, Koesoebiono et al,. Gramedia, Jakarta

1992. Biologi Laut suatu Pendekatan Ekologis. Diterjemahkan oleh H.M. Eidman, Koesoebiono et al,. Gramedia, Jakarta.

Rahman, F.A. 2009. Struktur Komunitas Makrozoobenthos di Perairan Estuaria Sungai Brantas (Sungai Porong dan Wonokromo), Jawa Timur. IPB, Bogor, $98 \mathrm{hlm}$.

Rosmarkam, A dan W.N. Yuwono. 2002. Ilmu Kesuburan Tanah. Kanisius, Yogyakarta.

Yuniar, A.S. 2012. Struktur Komunitas Makrozoobenthos di Perairan Morosari Kecamatan Sayung, Kabupaten Demak. Journal of Marine Research. Universitas Diponegoro, Semarang, 1(2):253-242.

Zahidin, M. 2008. Kajian Kualitas Air di Muara Sungai Pekalongan Ditinjau dari Indeks Keanekaragaman Makrobenthos dan Indeks Saprobitas Plankton. [Tesis]. Program Pascasarjana, Universitas Diponegoro, Semarang.

Zulfiandi. 2012. Struktur Komunitas Makrozoobenthos di Perairan Pandansari Kecamatan Sayung, Kabupaten Demak. Journal of Marine Research. Universitas Diponegoro, Semarang, 1(1):62-66. 